\title{
UJI BAKTERI PELARUT FOSFAT DAN PENGHASIL IAA PADA MOL BUAH BINTARO (Cerbera manghas L.)
}

\author{
Indah Mawar Rani ${ }^{1}$, Puji Riski Lestari ${ }^{2)}$, Dita Eka Rahmayani ${ }^{3)}$, Mat Asan ${ }^{4)}$, Meli Astriani ${ }^{5)}$ \\ 1223)445) Mahasiswa Prodi Pendidikan Biologi, FKIP Universitas Muhammadiyah Palembang \\ J1. Jendral Ahmad Yani, 13 Ulu, Kota Palembang, Sumatra Selatan 30252, Indonesia \\ Email: ${ }^{1)}$ mawar.indahmawar@gmail.com, ${ }^{2}$ pujiriski22@gmail.com, \\ ${ }^{3)}$ Ekarahmayanidita@gmail.com, ${ }^{4}$ matasan170297@gmail.com, ${ }^{5}$ meliastriani.g201@gmail.com
}

\section{Naskah diterima 26 Mei 2017 disetujui 29 Juni 2017}

\begin{abstract}
MOL contains superior microorganisms as decomposers activators of organic materials that can be used as plants fertilizer. The microorganisms that was contained in MOL was commercial biological agents. One way to get commercial biological agents was to look for potential bacteria that have a function as biofertilizer. The objective of this study was to screen for indigenous bacteria from MOL Bintaro fruit (Cerbera manghas L) that plays a role in the manufacture of biological fertilizers. The stages of this study were MOL making and sampling, sampling and bacterial screening by doing isolation and purification, continued by phosphate solvent bacteria test and IAA screening producing bacteria, then bacteria identification morphologically. The result of isolation and purification found that there were 35 kinds of bacteria from two samples of MOL Sample 1 was treated as $3 \mathrm{~kg}$ of Bintaro fruit and it was found that there were 18 bacteria. Furthermore, sample 2 was treated as $1.5 \mathrm{~kg}$ of Bintaro fruit and got 17 kinds of bacteria. The result of bacteria solvent screening found 7 isolates. The isolated bacteria that had the greatest solubility of phosphate were MBSD 6 with P isolated solvent index was $0.7 \mathrm{~cm}$. The screening results of IAA-producing bacteria showed that MBSD 7 produced the highest IAA was $37.36 \mathrm{ppm}$ and MBSP18 produced the lowest isolates was $6.27 \mathrm{ppm}$.
\end{abstract}

Keywords: Isolation, MOL, Cerbera manghas L. Fertilizer

\section{PENDAHULUAN}

Ketergantungan petani dalam menggunakan pupuk anoganik yang sangat tinggi dan berkurangnya pasokan pupuk bersubsidi dari pemerintah menimbulkan permasalahan tersendiri bagi para petani di seluruh wilayah Indonesia (Handayani, 2015). Alternatif dari penggunaan pupuk anorganik salah satunya dengan penggunaan kompos maupun pupuk cair organik. Pembuatan kompos dapat dilakukan secara alami, namun memiliki kekurangan yaitu proses yang dilakukan berlangsung lama. Semakin berkembangnya teknologi, masyarakat telah menemukan cara mempercepat pembuatan kompos yaitu dengan menambahkan Mikroorganisme Lokal (MOL).
MOL merupakan proses fermentasi dari berbagai limbah organik yang dipilih karena bernilai ekonomis. Pembuatan MOL yang biasa digunakan oleh masyarakat berasal dari berbagai limbah organik berupa sisa sayuran, buah, nasi, dan bonggol pisang. Cairan MOL yang telah dibuat mengandung mikroorganisme yang unggul sebagai aktivator dekomposer bahan organik dan dapat dijadikan sebagai penyubur tanaman. Mikroorganisme yang terdapat dalam MOL merupakan agen biologi yang komersial.

Salah satu cara mendapatkan agen biologi komersial yaitu dengan mencari potensi daribakteriyangmempunyai fungsi sebagai biofertilizer. MOL yang memiliki peran untuk meningkatkan pertumbuhan tanaman dan kesuburan tanah antara lain Rhizobium sp., Azospirillum sp., 
Azotobactersp., Pseudomonas sp., Bacillus sp., dan bakteri pelarut fosfat (Husen dan Irawan, 2008). Hasil identifikasi mikroba yang diisolasi dari MOL bonggol pisang teridentifikasi Bacillus sp., Aeromonas sp., dan Aspergillus niger (Suhastyo dkk, 2013). Bahan organik yang dapat dijadikan MOL yaitu memiliki kandungan selulosa. Buah bintaro (Cerbera manghas L.) merupakan buah yang beracun dan jarang untuk dimanfaatkan oleh masyarakat serta mengandung selulosa yang tinggi di dalam daging buahnya sebesar $41,8 \%$ (Yu dkk, 2008).

Pemanfaatan buah bintaro saat ini sebagai peptisida nabati (Towaha dkk, 2011), bioetanol dan karbon aktif (Iman dan Handoko, 2011). Penyebaran tanaman bintaro di Provinsi Sumatera Selatan keberadaannya banyak ditemukan di Kabupaten Banyuasin dan kegunaan buahnya belum dimanfatkan. Sehingga penelitian ini akan memberikan informasi pemanfaatan buahbintaro untuk pembuatan MOL. Selain itu, publikasi bakteri asal MOL buah bintaro belum ada dan belum pernah dilakukan penelitian. Oleh karena itu, penelitian ini perlu untuk dilakukan karena memberikan kontribusi bagi ilmu pengetahuan mengenai pembakuan formulasi MOL buah bintaro dan skrining bakteri dari MOL buah bintaro sebagai bakteri komersial. Bakteri unggul dan komersial hasil isolasi berpotensi untuk dijadikan sebagai pupuk hayati.

\section{METODE}

\section{Pembuatan MOL dan Pengambilan Sampel}

Bahan MOL berupa buah Bintaro dihancurkan kemudian dimasukkan ke dalam toples. Selanjutnya campurkan dengan gula merah sebagai molase sebanyak 200 gr. Tambahkan 5 liter air cucian beras aduk hingga rata. Semua campuran dimasukkan kedalam toples lalu ditutup dan lubangi tutupnya, kemudian hubungkan selang dari botol aqua yang berisi air murni Diamkan selama 21 hari agar terjadi fermentasi (modifikasi Kesumaningwati, 2015). Percobaan dibuat sebanyak 2 perlakuan yang terdiri atas: (1) Buah bintaro $3 \mathrm{~kg}$, molase, air cucian beras, (2) buah bintaro 1,5 kg, molase, air cucian beras.

Pengambilan sampel MOL sebanyak $5 \mathrm{~mL}$ dilakukan pada saat pembuatan MOL pada $1 \times 24$ jam (T0), minggu pertama pada $7 \times 24$ jam (T1), minggu ke-2 pada $14 \times 24$ jam (T2), minggu ke-3 pada $21 \times 24$ jam (T3) (Suhastyo dkk, 2013).

\section{Isolasi dan Pemurnian}

Sampel diambil sebanyak $1 \mathrm{ml}$ dan dilarutkan ke dalam larutan garam fisiologis $0,85 \%$, kemudian dihomogenkan dengan vortex. Pengenceran dibuat mulai $10^{-1}$ sampai $10^{-6}$. Digunakan pengenceran $10^{-4}, 10^{-5}, 10^{-6}$ untuk menumbuhkan bakteri pada medium NA dengan metode pour plate secara aseptis. Lalu diinkubasi pada suhu $37^{\circ} \mathrm{C}$ selama $2 \times 24$ jam, kemudian diamati koloni bakteri dan dilakukan penghitungan jumlah bakteri dalam satuan $\mathrm{Sel} / \mathrm{mL}$, koloni yang tumbuh dengan ciri berbeda dimurnikan dengan metode streak pada medium NA dan diinkubasi selama $2 \times 24$ jam pada suhu $37^{\circ} \mathrm{C}$. Selanjutnya isolat ditumbuhkan ke dalam medium NA miring sebagai stok kerja (Widjajanti dkk, 2006).

\section{Uji Bakteri Pelarut Fosfat}

Proses penapisan bakteri dilakukan dengan menguji bakteri pelarut fosfat menggunakan medium Pikovskaya. Menurut Mubarik (2014) bahan yang digunakan untuk membuat medium Pikovskaya yaitu: glukosa $10 \mathrm{~g} ; \mathrm{Ca}_{3}\left(\mathrm{PO}_{4}\right)_{2}$ $5 \mathrm{~g} ; \quad\left(\mathrm{NH}_{4}\right)_{2} \mathrm{SO}_{4} 0,5 \mathrm{~g} ; \mathrm{NaCl} 0,2 \mathrm{~g}$; $\mathrm{MgSO}_{4} 7 \mathrm{H}_{2} \quad 0,1 \mathrm{~g}$; yeast ekstrak $0,5 \mathrm{~g}$; $\mathrm{KCl} 0,2 \mathrm{~g} ; \mathrm{MnSO}_{4} 7 \mathrm{H}_{2} 0,002 \mathrm{~g} ; \mathrm{FeSO}_{4}$ $7 \mathrm{H}_{2} \mathrm{O} 0,002 \mathrm{~g}$, Semua bahan dilarutkan dalam 1L akuades dan dihomogenkan. Pembuatan medium Pikovskaya padat dilakukan dengan penambahan agar- 
agar sebanyak $15 \mathrm{~g}$. Medium tersebut disterilisasi menggunakan autoklaf pada tekanan $1 \mathrm{~atm}$ dengan suhu $121^{\circ} \mathrm{C}$ selama 20 menit dan diinkubasi pada suhu $37^{\circ} \mathrm{C}$ selama 3-7 hari. Zona bening yang terbentuk disekitar koloni diukur dengan: Indeks Pelarut Fosfat dengan diameter zona bening dikurangi diameter koloni dan hasilnya dibagi dengan diameter koloni sesuai dengan Mubarik dkk, (2014).

Indeks Pelarut Fosfat $=\frac{\text { Diameter Zona Bening-Diameter Koloni }}{}$

\section{Penapisan Bakteri penghasil IAA}

Proses penapisan bakteri penghasil IAA dilakukan dengan uji kualitatif dengan mode kalorimeter dengan menggunakan reagen Salkowski. Menurut Acuna dkk, (2011), Pembuatan reagen dilakukan dengan mencampurkan $\mathrm{H}_{2} \mathrm{SO}_{4} 150 \mathrm{ml}, \mathrm{FeCL}_{3} 6 \mathrm{H}^{2} \mathrm{O} 7,5 \mathrm{~mL}$; dan akuades. Kemudian disimpan dalam botol yang tidak tembus cahaya. Menurut A'Ini (2013), Dilanjutkan dengan analisis secara kuantitatif menggunakan metode spektrofotometri dengan menggunakan NB yang ditambahkan precursor L-Tryptophan 0,5 Mm pada media yang telah streril. Ambil kultur sebanyak 1 $\mathrm{mL}$ lalu di sentrifuge. Lalu supernatan sebanyak $1 \mathrm{~mL}$ di reaksikan dengan reagen salkowaki dan diinkubasi pada ruang gelap selama 15 menit dan dihomogenkan, kemudian ukur absorbansi dengan menggunakan spektrofotometer dengan panjang gelombang $520 \mathrm{~nm}$ berdasarkan warna yang akan dihasilkan merah muda, menandakan bakteri dapat menghasilkan IAA yang dihasilkan dari reaksi antara reagen Salkowski dan IAA.

\section{Identifikasi Morfologi}

Identifikasi morfologi koloni meliputi pengamatan koloni bakteri pada medium Nutrient Agar lempeng, lalu diamati bentuk pertumbuhan yang meliputi bentuk koloni standar, bentuk elevasi, tepi dan struktur dalam koloni bakteri. Bakteri ditumbuhkan pada NA tegak medium NA miring dan medium NB pada suhu $37^{\circ} \mathrm{C}$ kemudian diamati pertumbuhan (aerob, fakultatif, anaerob dan mikroaerofil) dari masing-masing isolat.

Identifikasi morfologi sel dengan pewarnaan differensial yang terdiri dari 4 jenis pewarnaan yaitu kristal violet, iodium, Alkohol 95\%, dan safranin. Amati preparat dibawah mikroskop jika warna ungu maka sel bakteri tergolong Gram positif dan warna merah tergolong Gram negatif. Diamati pula bentuk dari sel bakteri tersebut apakah bulat (coccus), batang (basil), atau bergelombang (spiral) (Djide dan Sartini, 2008).

\section{Penyajian Data}

Data yang diperoleh dari pengamatan disajikan dalam bentuk foto dan tabel.

\section{HASIL DAN PEMBAHASAN}

Sampel MOL buah bintaro dibuat sebanyak 2 perlakuan yang terdiri atas MOL ke-1) Buah bintaro $3 \mathrm{~kg}$, molase, air cucian beras, (2) buah bintaro 1,5 kg, molase, air cucian beras. Hasil isolasi dan pemurnian bakteri asal MOL buah Bintaro selama 21 hari di dapatkan 35 jenis bakteri yang berasal dari dua sampel MOL. Sampel 1 dengan perlakuan $3 \mathrm{~kg}$ buah Bintaro, molase, air cucian beras didapatkan 18 jumah jenis bakteri dan sampel 2 dengan perlakuan 1,5 kg Buah Bintaro, molase, air cucian beras didapatkan 17 jumlah jenis bakteri data ditampilkan pada (Tabel 1). MOL dibuat sebagai media hidup dan mengandung mikroorganisme yang dapat bersifat dekomposisi bahan organik dan memiliki potensi sebagai pemacu pertumbuhan tanaman (Astriani, 2017).

Berdasarkan hasil isolasi dapat dilihat pada Tabel.1 bahwa diperoleh data secara keseluruhan antara sampel MOL ke-I dan II jumlah sel bakteri tertinggi terdapat pada sampel MOL ke- I dengan total 18 jumlah jenis bakteri paling banyak. Faktor yang mempengaruhi tumbuhnya 
bakteri dalam fermentasi yaitu substrat, $\mathrm{pH}$, oksigen dan mikroba yang digunakan (Budiyani, 2016). Substrat merupakan sumber utama yang dibutuhkan mikrobia untuk tumbuh. Sumber utamanya karbohidrat dan glukosa, yang berasal dari gula merah dan air cucian beras, dan buah bintaro sebagai sumber mikrobia yang digunakan. Proses yang terjadi dalam pembuatan MOL adalah proses fermentasi. Fermentasi merupakan proses oksidasi anaerob karbohidrat yang akan menghasilkan alkohol dan asam-asam, dan juga pada proses fermentasi akan terjadinya dekomposisi pada bentuk fisik dan juga pembebasan sejumlah unsur dalam bentuk senyawa yang kompleks maupun senyawa yang sederhana. Aktivitas dari mikrobia dalam mendekomposisi akan menghasilkan gas $\mathrm{CO}_{2}$ yang akan membentuk asam karbonat $\left(\mathrm{H}_{2} \mathrm{CO}_{2}\right)$ yang mudah terurai menjadi $\mathrm{H}_{2} \mathrm{CO}_{3}^{-}$dan $\mathrm{H}^{+}$. Ion $\mathrm{H}^{+}$akan menurunkan keasaman MOL (Handayani, 2015).

Tabel 1. Jumlah Total Jenis Bakteri

\begin{tabular}{|c|c|c|c|c|}
\hline Asal Sampel & Waktu & $\begin{array}{l}\text { Jumlah Sel } \\
\text { Bakteri (sel/ } \\
\text { ml) }\end{array}$ & $\begin{array}{l}\text { Jumlah } \\
\text { Jenis } \\
\text { Bakteri }\end{array}$ & Kode Isolat \\
\hline \multirow{4}{*}{$\begin{array}{l}\text { MOL I } \\
\text { (Perlakuan } \\
3 \text { kg Buah } \\
\text { Bintaro) }\end{array}$} & T0 & $4,3 \times 10^{7}$ & 4 & MBSP1,MBSP2,MBSP3,MBSP4 \\
\hline & $\mathrm{T} 1$ & $8,3 \times 10^{7}$ & 9 & $\begin{array}{l}\text { MBSP1,MBSP5,MBSP6,MBSP7,MBSP8, } \\
\text { MBSP9,MBSP10,MBSP11,MBSP12 }\end{array}$ \\
\hline & $\mathrm{T} 2$ & $5,9 \times 10^{7}$ & 6 & $\begin{array}{l}\text { MBSP 6,MBSP 13,MBSP 9,MBSP } \\
\text { 14,MBSP7,MBSP } 5\end{array}$ \\
\hline & $\mathrm{T} 3$ & $5,1 \times 10^{7}$ & 8 & $\begin{array}{l}\text { MBSP 15, MBSP 16,MBSP 6,MBSP } \\
17, \text { MBSP 9,MBSP 18,MBSP 12,MBSP } 7\end{array}$ \\
\hline \multicolumn{3}{|c|}{ Total Jumlah Jenis } & 18 & \\
\hline \multirow[t]{4}{*}{$\begin{array}{l}\text { MOL II } \\
\text { (Perlakuan } \\
1,5 \mathrm{~kg} \text { Buah } \\
\text { Bintaro) }\end{array}$} & T0 & $2,4 \times 10^{7}$ & 9 & $\begin{array}{l}\text { MBSD 1,MBSD 2,MBSD 3,MBSD 4, } \\
\text { MBSD 5,MBSD 6,MBSD 7,MBSD } 8 \text {, } \\
\text { MBSD } 9\end{array}$ \\
\hline & $\mathrm{T} 1$ & $7,1 \times 10^{7}$ & 6 & $\begin{array}{l}\text { MBSD1, MBSD 2,MBSD 10,MBSD } \\
11, \text { MBSD 9,MBSD } 8\end{array}$ \\
\hline & $\mathrm{T} 2$ & $4,1 \times 10^{7}$ & 7 & $\begin{array}{l}\text { MBSD 7,MBSD 12,MBSD 13,MBSD } \\
\text { 9,MBSD 3,MBSD 1,MBSD } 14\end{array}$ \\
\hline & $\mathrm{T} 3$ & $7,2 \times 10^{7}$ & 6 & $\begin{array}{l}\text { MBSD 15,MBSD 3,MBSD 4,MBSD } \\
\text { 6,MBSD 16,MBSD } 17\end{array}$ \\
\hline
\end{tabular}

Total Jumlah Jenis

17

Keterangan: 1 x 24 jam (T0); 7 x 24 jam (T1); 14 x 24 jam (T2); 21 x 24 jam (T3); MBSP = Mol Buah Sampel Pertama; MBSD = Mol Buah Sampel Dua; Total Jumlah Jenis Bakteri 18=Isolat MBSP 1-MBSP 18 untuk kurunwaktu (T0-T3) ; Total Jumlah Jenis Bakteri 17=Isolat MBSD 1-MBSD 17 untuk kurun waktu (T0-T3)

Berdasarkan grafik TPC (Total Plate Count) (Gambar1). Menunjukkan untuk sampel 1 Pada waktu T0 jumlah jenis bakteri yaitu sekitar $4,3 \times 107 \mathrm{sel} / \mathrm{mL}$ hal ini menandakan bakteri dalam fase adaptasi terhadap lingkungan barunya, hal ini sesuai dengan pendapat Mangunwidjaja dan Suryani (2010), jika mikroba dipindahkan ke dalam suatu media, mula-mula akan mengalami fase adaptasi untuk menyesuaikan diri dengan kondisi lingkungan di sekitarnya. Kemudian pada waktu T1 bakteri mulai tumbuh menjadi $8,3 \times 10^{7} \mathrm{sel} / \mathrm{mL}$ pada fase ini terjadi fase logaritmatik dimanan bakteri mulai mampu memanfaatkan substrat yang ada untuk membelah, Pada fase logaritmik mikroba membelah dengan cepat dan konstan dan pada fase ini kecepatan pertumbuhan sangat dipengaruhi oleh media tempat 
tumbuhnya seperti $\mathrm{pH}$ dan kandungan nutrien, juga kondisi lingkungan termasuk suhu dan kelembaban udara (Yuliana, 2008). Minggu ke-2 pada waktu T2 bakteri dalam fase statis, jumlah substrat makin lama makin berkurang menjadi $5,9 \times 10^{7} \mathrm{sel} / \mathrm{mL}$, sehingga populasi bakteri mengalami penurunan yang biasanya disebabkan karena kekurangan faktor pertumbuhan seperti vitamin dan unsur mineral (Yuliana, 2008). Berhentinya pertumbuhan juga dapat disebabkan oleh berkurangnya beberapa nutrien esensial dalam media atau karena terjadinya akumulasi autotoksin dalam media atau kombinasi dari keduanya (Yuliana, 2008).

Kemudian pada Minggu ke-3 pada waktu T3 bakteri mengalami fase kematian ditandai dengan makin berkurangnya jumlah populasi bakteri menjadi $5,1 \times 10^{7}$ sel/mL.Jumlah sel yang mati semakin lama akan semakin banyak. Kematian sel bakteri pada fase ini disebabkan karena nutrisi dalam media dan energi yang dibutuhkan sudah habis. Fase kematian bakteri dicirikan dengan kematian sel lebih cepat dari pada pertumbuhan sel, laju kematian menjadi lebih cepat dan semua selakan mati dalam waktu tertentu sesuai spesiesnya (Pelczar dan Chan, 2014).

Hal yang sama juga terjadi pada sampel 2 pada waktu T0 bakteri berada dalam fase adaptasi (penyesuaian) terhadap lingkungannya ditujukan dengan jumlah jenis bakteri yaitu $2,4 \times 10^{7} \mathrm{sel} / \mathrm{mL}$. Kemudian waktu T1 bakteri memasuki fase logaritmatik atau fase pertumbuhan bakteri yang dicirikan dengan adanya penigkatan populasi bakteri yang cukup signifikan menjadi $7,1 \times 10^{7} \quad \mathrm{sel} / \mathrm{mL}$. Selanjutnya pada waktu T2 pertumbuhan bakteri mengalami penurunan menjadi
$4,1 \times 10^{7} \mathrm{sel} / \mathrm{mL}$, dan terakhir pada waktu T3 grafik menunjukkan kenaikan hingga jumlah jenis bakteri mencapai $7,2 \times 10^{7}$ $\mathrm{sel} / \mathrm{mL}$, hal ini diduga karena beberapa isolat masih memungkinkan untuk mengalami fase pertumbuhan lebih lanjut dalam waktu yang lebih lama dari waktu inkubasi dan belum memasuki fase kematian (Saragih, 2013).

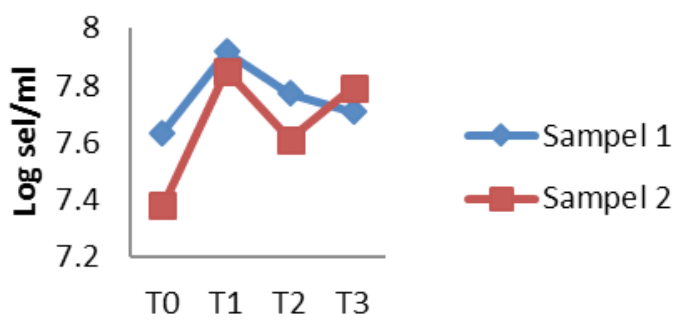

Gambar 1. Grafik TPC (Total Plate Count) Keterangan: 1 x 24 jam (T0); 7 x 24 jam (T1);14 x 24jam (T2); 21 x 24 jam (T3);Sampel 1 (3kg buah Bintaro); Sampel 2 (1,5 kg buah Bintaro).

Uji pelarut fosfat menunjukkan Dari 35 isolat terdapat 7 isolat yang membentuk zona bening disekeliling koloni seperti pada (Gambar 2). George dkk. (2002) menyatakan bahwa Terbentuknya zona bening disekitar koloni menunjukkan bahwa isolat tersebut mampu menghasilkan asam organik ekstraseluler yang mampu berikatan dengan ion $\mathrm{Ca}$ yang terikat dalam bentuk $\mathrm{Ca} 3(\mathrm{PO} 4) 2$ pada media Pikovskaya agar dan membebaskan ion $\mathrm{H} 2 \mathrm{PO} 4$ sehingga membentuk area yang berwarna lebih jernih daripada area yang masih memiliki $\mathrm{P}$ terikat. Menurut Maryati (2006), asam organik tersebut dapat berupa asam sitrat, glutamat, suksinat, laktat, oksalat, glikooksalat, malat, fumarat, tartarat ataupun asam alpha-ketobutirat. 

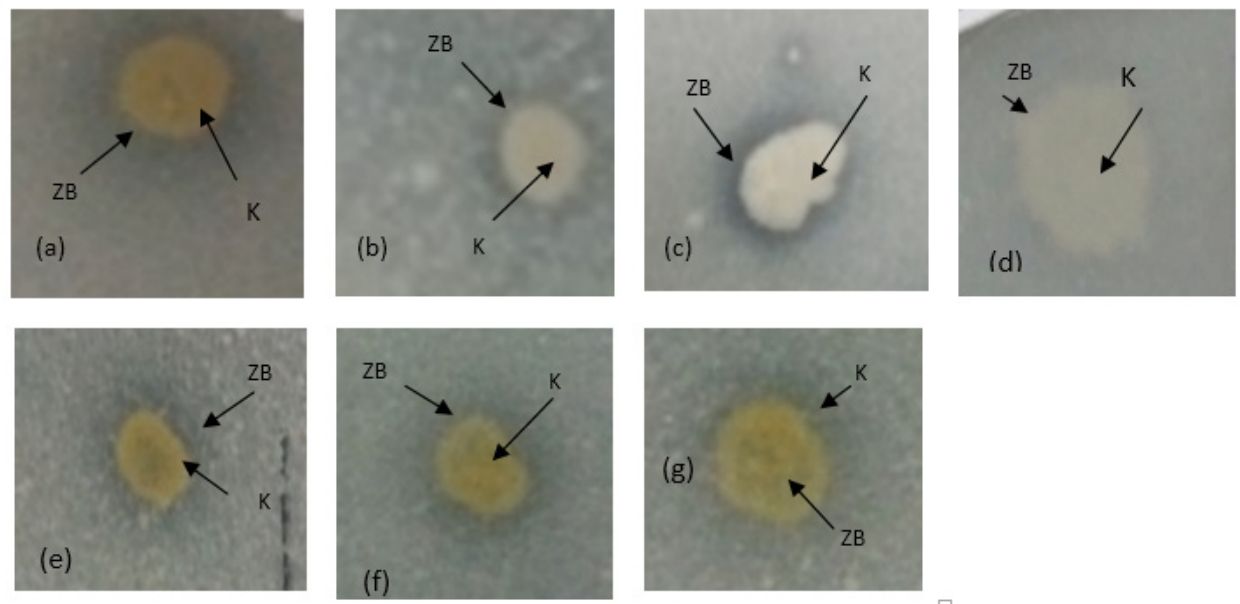

Gambar 2. Koloni Bakteri Pada Medium Pikovskayayang Menunjukkan Zona Bening Keterangan: ZB= Zona Bening; K= Koloni Isolat; (a) MBSP 1;(b) MBSP 10; (c) MBSP 14; (d) MBSP

17; (e) MBSD 6;(f) MBSD 9; (g) MBSD 10.

Kemampuan bakteri dalam melarutkan fosfat dinyatakan dalam bentuk Indeks Pelarut Fosfat. Isolat bakteri yang memiliki kemampuan melarutkan fosfat paling besar yaitui solat MBSD 6 dengan indeks pelarut $\mathrm{P}$ sebesar $0,7 \mathrm{~cm}$. Bakteri yang memiliki zona bening terbesar selanjutnya yaitu MBSP 1, MBSD 10 dan MBSP 17, MBSD 9 sebesar 0,7 $\mathrm{cm}$ dan $0,6 \mathrm{~cm}$ (Tabel 2).

Tabel 2. Hasil Perhitungan Bakteri Pelarut Fosfat

\begin{tabular}{cccc}
\hline KodeIsolat & $\begin{array}{c}\text { DK } \\
(\mathbf{c m})\end{array}$ & $\begin{array}{c}\text { DZB } \\
(\mathbf{c m})\end{array}$ & $\begin{array}{c}\text { Indeks } \\
\text { Pelarut } \\
\text { Fosfat }(\mathbf{c m})\end{array}$ \\
\hline MBSP 1 & 0,5 & 0,7 & 0,4 \\
MBSP 10 & 0,2 & 0,3 & 0,5 \\
MBSP 14 & 0,4 & 0,5 & 0,4 \\
MBSP 17 & 0,5 & 0,6 & 0,2 \\
MBSD 6 & 0,4 & 0,7 & 0,7 \\
MBSD 9 & 0,5 & 0,6 & 0,2 \\
MBSD 10 & 0,5 & 0,7 & 0,4 \\
\hline
\end{tabular}

Keterangan : DK = diameter koloni;

$\mathrm{DZB}=$ diameter zonabening

Bakteri yang telah terpilih dalam proses uji pelarut fosfat kemudian dilakuakan uji perwarnaan gram. Perwarnaan gram dilakukan untuk mengelompokkan bakteri menjadi 2 yaitu Gram positif dan Gram negatif. Pada pewarnaan Gram, hasil yang didapati akan ditentukan dari komposisi dinding sel pada bakteri. Pada pewarnaan Gram ini, reagen yang digunakan ada 4 jenis, yaitu Kristal violet, iodin, alkohol dan safranin. Bakteri gram positif akan mempertahankan warna ungu dari Kristal violet sehingga ketika diamati dengan mikroskop akan menunjukan warna ungu sedangkan bakteri Gram negatif tidak dapat mempertahankan warna ungu dari Kristal violet tetapi zat warna safranin dapat terserap pada dinding sel (Pratita \& Putra, 2012).

Hasil pewarnaan Gram menunjukkan bahwa bakteri terpilih dari hasil skrining memiliki bentuk coccus negatif yaitu MBSD 6 dan MBSD 10, bakteri coccus positif yaitu MBSP 1, MBSP 17, dan bentuk basil negatif yaitu MBSD 9 (Tabel 4).

Tabel 3. Hasil Pewarnaan Gram BakteriTerpilih

\begin{tabular}{lll}
\hline Kode Isolat & Jenis Bakteri & $\begin{array}{l}\text { Bentuk } \\
\text { Bakteri }\end{array}$ \\
\hline MBSP 1 & Gram Positif & Coccus \\
MBSP 10 & Gram Positif & Coccus \\
MBSP 14 & Gram Positif & Coccus \\
MBSP 17 & Gram Positif & Coccus \\
MBSD 6 & Gram Negatif & Coccus \\
MBSD 9 & Gram Negatif & Basil \\
MBSD 10 & Gram Negatif & Coccus \\
\hline
\end{tabular}


Perbedaan bentuk dan warna tersebut pada bakteri gram positif dan negatif menunjukan bahwa adanya perbedaan struktur dinding sel antara kedua jenis bakteri tersebut (Gambar 3). Bakteri gram positif memiliki kandungan

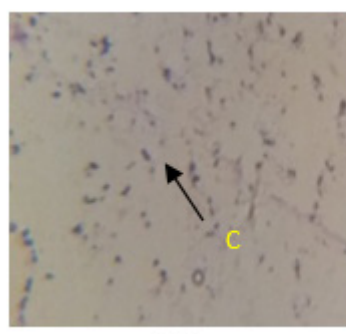

(a)

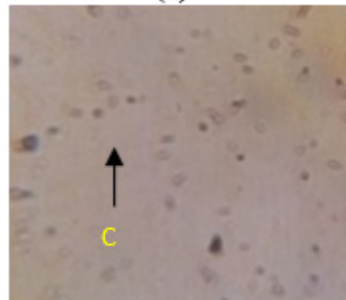

(e)

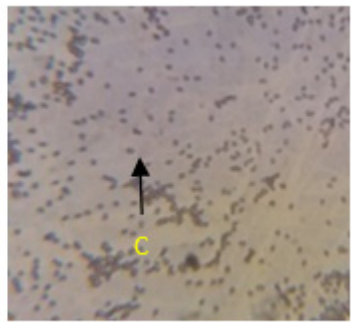

(b)

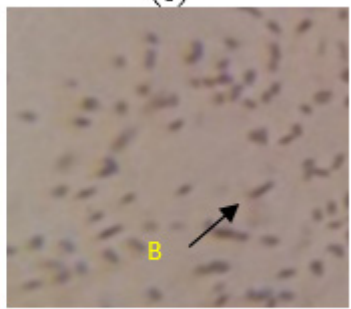

(f) struktur dinding sel dengan kandungan peptidoglikan yang tebal sedangkan bakteri gram negatif memiliki struktur dinding sel dengan kandungan lipid yang tinggi (Fitri \& Yasmin,2011).

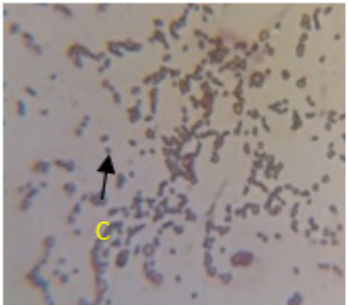

(c)

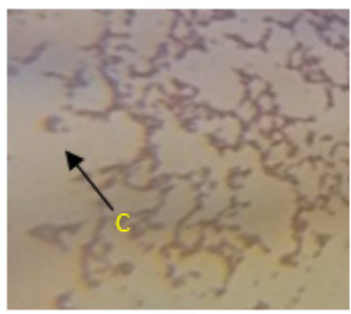

(g)

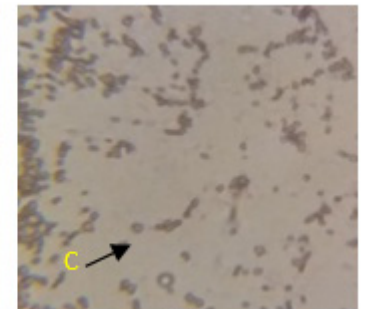

(d)

Gambar 3. Hasil Pewarnaan Bakteri Pelarut Fosfat dengan Perbesaran 100× Keterangan: $\mathrm{C}=$ Bakteri Coccus; $\mathrm{B}=$ Bakteri Basil; (a) MBSP 1; (b) MBSP 10;(c) MBSP 14; (d) MBSP 17; (e) MBSD 6; (f) MBSD 9; (g) MBSD 10.

Uji kuantitatif terhadap 35 isolat bakteri dengan menggunakan spektrofotometer, menunjukan bahwa semua kultur isolat yang ditambahkan Ltriptopan 0,5 Mm mampu menghasilkan IAA dengan konsentrasi IAA bervariasi dari masing-masing isolat.Isolat MBSD 7 menghasilkan IAA tertinggi sebesar 37,36 ppmdan MBSP 8 menghasilkan isolat yang terendah yaitu3,36 ppm (Tabel 5).

Variasi konsentrasi hormon IAA yang dihasilkan oleh masingmasing isolat diduga karena perbedaan kemampuan kecepatan bakteri dalam menggunakan triptopan sebagai percusor untuk membentuk IAA. Biosintesis IAA oleh mikroba ditingkatkan oleh prekursor fisiologi tertentu yaitu L-Tryptophan (Husen, 2003). L-Tryptophan merupakan asam amino yang berfungsi sebagai prekusor dalam biosintesis auxin (IAA) pada tanaman dan mikroba (Patil et al. 2011). Penambahan L-Tryptophan pada media kultur dapat meningkatkan produksi IAA. L-Tryptophan mengandung sumber senyawa aktif yang dapat memicu pertumbuhan mikrobaiota rhizosfer dan endofit (Dewi, 2016). Penelitian yang dilakukan Patten dan Glick (2002) diperoleh bahwa bakteri yang memproduksi IAA akan menstimulasi pertumbuhan sistem perakaran inang. Keuntungan dari asosiasi tanaman dengan bakteri adalah mensuplai sebanyak produk metabolit fiksasi karbon oleh tumbuhan yang telah hilang ke rizosfer sebagai eksudat 
Uji Bakteri Pelarut Fosfat dan Penghasil IAA pada Mol Buah Bintaro (Cerbera manghas L).

Tabel 4. Hasil Uji Konsentasi Bakteri Penghasil IAA

\begin{tabular}{|c|c|c|c|c|}
\hline $\begin{array}{c}\text { Asal } \\
\text { sampel }\end{array}$ & Total isolat & Kodeisolat & $\begin{array}{l}\text { Nilai OD pada } \\
\lambda=520 \mathrm{~nm}\end{array}$ & $\begin{array}{c}\text { Nilaikonsentrasi IAA } \\
\text { ditambahkan L T-triptopan } \\
(\text { ppm) }\end{array}$ \\
\hline \multirow[t]{18}{*}{ Sampel 1} & 2 & MBSP 1 & 0,134 & 11,18 \\
\hline & 1 & MBSP 2 & 0,217 & 18,72 \\
\hline & 1 & MBSP 3 & 0,156 & 13,18 \\
\hline & 1 & MBSP 4 & 0,270 & {$[23,54]$} \\
\hline & 2 & MBSP 5 & 0,124 & 10,27 \\
\hline & 3 & MBSP 6 & 0,177 & 15,09 \\
\hline & 3 & MBSP 7 & 0,276 & {$[24,09]$} \\
\hline & 1 & MBSP 8 & 0,048 & 3,36 \\
\hline & 3 & MBSP 9 & 0,218 & 18,81 \\
\hline & 1 & MBSP 10 & 0,180 & 15,36 \\
\hline & 1 & MBSP 11 & 0,093 & 7,45 \\
\hline & 2 & MBSP 12 & 0,199 & 17,09 \\
\hline & 1 & MBSP 13 & 0,224 & 19,36 \\
\hline & 1 & MBSP 14 & 0,115 & 9,45 \\
\hline & 1 & MBSP 15 & 0,179 & 15,27 \\
\hline & 1 & MBSP 16 & 0,205 & 17,63 \\
\hline & 1 & MBSP 17 & 0,315 & {$[27,63]$} \\
\hline & 1 & MBSP 18 & 0,080 & 6,27 \\
\hline \multirow[t]{17}{*}{ Sampel 2} & 3 & MBSD 1 & 0,272 & {$[23,72]$} \\
\hline & 2 & MBSD 2 & 0,092 & 7,36 \\
\hline & 3 & MBSD 3 & 0,254 & {$[22,09]$} \\
\hline & 2 & MBSD 4 & 0,202 & 17,36 \\
\hline & 1 & MBSD 5 & 0,163 & 13,81 \\
\hline & 2 & MBSD 6 & 0,209 & 18,00 \\
\hline & 2 & MBSD 7 & 0,422 & {$[37,36]$} \\
\hline & 2 & MBSD 8 & 0,113 & 9,27 \\
\hline & 3 & MBSD 9 & 0,138 & 11,54 \\
\hline & 1 & MBSD 10 & 0,129 & 10,72 \\
\hline & 1 & MBSD 11 & 0,162 & 13,72 \\
\hline & 1 & MBSD 12 & 0,206 & 17,72 \\
\hline & 1 & MBSD 13 & 0,121 & 10,00 \\
\hline & 1 & MBSD 14 & 0,151 & 12,72 \\
\hline & 1 & MBSD 15 & 0,292 & {$[25,54]$} \\
\hline & 1 & MBSD 16 & 0,135 & 11,27 \\
\hline & 1 & MBSD 17 & 0,092 & 7,36 \\
\hline
\end{tabular}

Keterangan: $\mathrm{IAA}=$ Indole Acetic Acid; MBSP $=$ Mol Buah Sampel Pertama;MBSD $=$ Mol Buah Sampel Dua 
Rani, dkk

\section{SIMPULAN}

Hasil isolasi dan pemurnian serta skrining bakteri unggul asal MOL buah Bintaro diperoleh simpulan sebagai berikut:

1. Sampel 1 dengan perlakuan $3 \mathrm{~kg}$ buah Bintaro didapatkan 18 jumlah jenis bakteri dan sampel 2 dengan perlakuan 1,5 kg Buah Bintaro didapatkan 17 jumlah jenis bakteri.

2. Uji bakteri pelarut fosfat diperoleh 4 isolat dari sampel MOL 1 dan 3 isolat dari sampel MOL 2 Isolat bakteri yang memiliki kemampuan melarutkan fosfat paling besar yaitu MBSD 6 dengan indeks pelarut $\mathrm{P}$ sebesar 0,7 $\mathrm{cm}$. Berdasarkan pewarnaan Gram, Bakteri terpilih dari hasil skrining memiliki bentuk coccus negatif yaitu MBSD 6 dan MBSD 10, bakteri coccus positif yaitu MBSP 1, MBSP 10, MBSP 14, MBSP 17, dan bentuk basil negatif yaitu MBSD 9.

3. Penapisan Bakteri penghasil IAA menunjukkan Isolat MBSD 7 menghasilkan IAA tertinggi sebesar 37,36 ppm kemudian tertinggi selanjutnya MPSP 17,MBSD 15, MBSP 7, MBSD 1, MBSP 4, dan MBSD 3.dengan konsentrasi diatas 20 ppm dan MBSP 8 menghasilkan isolat yang terendah yaitu $3,36 \mathrm{ppm}$ dan terendah selanjutnya MBSP 18, MBSD 2, MBSD 17, MBSP 11, MBSD 8, MBSP 14, dan dengan konsentrasi dibawah $10 \mathrm{ppm}$.

\section{UCAPAN TERIMA KASIH}

Direktorat Kemahasiswaan.

Direktorat Jendral Pembelajaran dan Kemahasiswaan Kementrian Riset Teknologi dan Pendidikan Tinggi Sesuai dengan surat perjanjian penugasan Program Kreativitas Mahasiswa (PKM) 5 bidang tahun 2017-05-12 Nomor 105/ SPK/KM/III/2017 Tanggal 31 Maret 2017.

\section{DAFTAR PUSTAKA}

Acuna,J,J. Jorquera, M,A. Martinez, O,A. Blackburn, M. Fernandez, M,T. Marschner, P. Greiner, R. Mora, M,L. (2011). Indole Acetic Acid and Phytase Activity Produced By Rhizosphere Bacilli As Affected By $\mathrm{pH}$ and Metals. Journal Of Soll Sclence and Plant Nutrition, 11(3): 4.

A'Ini, Z,F. (2013). Isolasi dan Identifikasi Bakteri Penghasil IAA (Indole-3Acid) dari Tanah dan Air Situgunung, Sukabumi. Faktor Exacta, 6(3): 224.

Arief, R.W., I. Irawati., dan Yusmasari. (2011). Penurunan Kadar Asam Fitat Tepung Jagung Selama Proses Fermentasi menggunakan Ragi Tape. Lampung. Seminar Nasional Serelia 2011.

Astriani, M.Mukaromah, E. (2017). Penggunaan Strategi Inkuiri dalam Pembelajaran Isolasi Bakteri Asal MOL dan Penerapanya Sebagai Pupuk Hayati. Florea, 4(1):20.

Astari, W. Purwani, K.I. Anugerahani, W. (2014).Pengaruh aplikasi pupuk hayati terhadap pertumbuhan dan produktivitas tanaman tomat (Solanumlycopersicum L.) Var. Tombatu di PT Petrokimia Gresik. Jurnal Sains dan Seni Pomits. 2(1): $1-4$.

Budiyani, N,K. Soniari, N,N. Sutari, N, W,S. (2016). Analisis Kualitas Larutan Mikroorganisme Lokal (MOL) Bonggol Pisang. E-Jurnal Agroekoteknologi Tropika, 5 (1): 67-68.

Djide, M.N. dan Sartini. (2008). DasarDasar Mikrobiologi Teknologi Laboratorium Kesehatan. Makassar: Fakultas Farmasi Universitas Hasanuddin.

Dewi, T, K. Anggono, J, S. Agustiyani, D. 2016. Isolasi Dan Uji Aktivitas Bakteri Penghasil H o r m o n Tumbuh IAA (Indole-3-Acetic 
Uji Bakteri Pelarut Fosfat dan Penghasil IAA pada Mol Buah Bintaro (Cerbera manghas L).

Acid) dan Bakteri Perombak Protein Dari Tanah Pertanian Tual, Maluku Tenggara. Pros Sem Nas Masy Biodiv Indon, 2(2): 272 - 273.

Fitri, L., dan Yasmin, Y. (2011). Isolasi dan Pengamatan Morfologi Koloni Bakteri Kitinolitik. Jurnal Biologi Edukasi. 3(2): 20-25.

Handayani, S.H. Yunus, A. Susilowati, A.(2015). Uji kualitas pupuk organik cair dari berbagai macam mikroorganisme lokal (MOL). ElVivo. 3(1): 54-60.

Handoko, T. Suhandiaya, G. Mulyana, H. (2012). Hidrolisis serat selulosa dalam buah bintaro sebagai sumber bahan baku bioetanol. Jurnal Teknik Kimia Indonesia. 11(1): 26-33.

Husen, E.dan Irawan. $\quad\left(\begin{array}{llll}2 & 0 & 0 & 8\end{array}\right)$. Efektivitas dan efisiens mikroba decomposer komersial dan local dalam pembuatan kompos jerami. http://balittanah.litbang. pertanian.go.id/ind/dokumentasi/ prosiding2008pdf/edihusen.pdf. Diakses tanggal 28 Oktober 2016.

Iman, G. danHandoko, T. (2011). Pengolahan buah bintaro sebagai sumber bioetanol dan karbon aktif. Prosiding Seminar Nasional Teknik Kimia "Kejuangan” Pengembangan Teknologi Kimia untuk Pengolahan Sumber Daya Alam Indonesia. 22 Februari 2011, Yogyakarta, Indonesia. Hal. 1-5.

Kartimi.(2015). Pemanfaatan buah bintaro sebagai biopeptisida dalam penanggulangan hama pada tanaman padi di kawasan pesisir desa bandengan Kabupaten Cirebon.

Prosiding Seminar Nasional Pendidikan Biologi 2015. 21 Maret 2015, Malang, Indonesia. Hal. 101111.

Kesumaningwati R. (2015). Penggunaaan MOL bonggol pisang (Musa paradisiaca) sebagai dekomposer untuk pengomposan tandan kosong kelapa sawit. JZiraa'ah. 40 (1): 4045.

Maryanti,D.(2006).Isolasi dan uji kemampuan bakteri pelarut fosfat dari rhizosfir tanaman pangan dan semak. Skripsi. Fakultas Pertanian Universitas Andalas, Padang.

Mangunwidjaja, D. dan A. Suryani. (2010). Teknologi Bioproses. Penerbit Swadaya. Jakarta. 394 hlm.

Mubarik, N,R. Wibowo, R,H. anggraini, E. Mursyida, E. Wahdi, E. (2014). Exploration of Bacterial Diversity at Cirebon Quarry. Department of Biology, Faculty of Mathematics and Natural Sciences, Bogor Agricultural University.

Patten, C.L., Glick, B.R. 2002. Role of Pseudomonas putida indole acetic acid in development of the the plant root system. Appl Environ Microbial J.IImu Pert. Indonesia 183 68: 3795 $-3801$.

Pelczar, M.J. dan Chan. ECs. (2014). Dasar-Dasar Mikrobiologi. Universitas Indonesia: Jakarta.

Prayuda, Y.E. (2014). Efikasi Ekstrak Biji Bintaro (Cerbera manghas) Sebagai Larvasida Pada Larva Aedes aegypti L. Instar III/IV. Skripsi. Fakultas Kedokteran dan Ilmu Kesehatan Uin Syarif Hidayatullah, Jakarta.

Partita, M. Y. E. dan Putra, S. R. (2012). Isolasi Dan Identifikasi Bakteri Termofilik dari Sumber Mata Air Panas di Songgoriti Setelah Dua Hari Inkubasi. Jurnal Teknik POMITS. 1(1): 1-5.

Purwasasmita M, Kunia K. (2009). Mikroorganisme lokal sebagai pemicu siklus kehidupan dalam bioreaktor tanaman. Seminar Nasional Teknik Kimia IndonesiaSNTKI 2009. Bandung 19-20 Oktober 2009.

Saragih. A. B. (2013). Skrining Bakteri Pelarut Fosfat Adaptif Vinasse dari Lahan Tebu Pabrik Gula Jatiroto 
Kabupaten Lumajang Jawa Timur. Skripsi. Jember: Program Studi Biologi. Fakultas Matematika dan Ilmu Pengetahuan Alam. Universitas Jember.

Suhastyo, A.A. Anas, I. Santosa, D.A. Lestari, Y.(2013). Studi mikrobiologi dan sifat kimia mikroorganisme lokal (mol) yang digunakan pada budidaya padi metode SRI (System Of Rice Intensification). Sainteks. 10(2): 29-39.

Sutari, N. W. S. (2010). Uji Berbagai Jenis Pupuk Cair Biourine terhadap Pertumbuhan dan Hasil Tanaman Sawi Hijau (Brassica juncea L.). Agritrop : Jurnal Ilmu-Ilmu Pertanian (Journal On Agricultural Sciences) edisi desember 2010. Vol.29.

Towaha, J. dan Indriati, G. (2011). Bintaro (Cerbera manghas) sebagai peptisida nabati. Warta Penelitian dan Pengembangan Tanaman Industri. 17(1) : 1-6.

Widjajanti, H. Munawar, Nafiah. (2006). Isolasi, Seleksi, dan Karakterisasi Bakteri Hidrokarbonoklastik dari Limbah Cair Kegiatan Eksplorasi Minyak Bumi. Jurnal Pengelolahan Lingkungan \& Sumber Daya Alam. 6(4):22-31

Yuliana. N. (2008). Kinetika Pertumbuhan Bakteri Asam Laktat Isolat T5 yang Berasal dari Tempoyak. Jurnal Teknologi Industri dan Hasil Pertanian. Vol.13. No.2 Hal.109116.

Yun, Y. Xia, L. Hongwei, W. (2008). Some Recent Advances in Hydrolysis of Biomass in Hot Compressed Water and Its Comparisons with Other Hydrolysis Methods. Energy Fuels.22. 